\title{
Silvia Scatena,
}

Od prawie osiemdziesięciu lat, świat słyszy o założonej w pobliżu dawnych murów opactwa benedyktyńskiego w Cluny, ekumenicznej Wspólnocie braci z Taizé. Jej założyciel, brat Roger Schutz, głęboko poruszony szalejącą w Europie wojną oraz brakiem widocznej jedności wśród chrześcijan postanowił realizować wraz z innymi braćmi przypowieść o Wspólnocie. Chociaż od początków jej powstania mija tyle już lat, to nadal bracia poprzez wspólną modlitwę, własną pracę oraz spotkania z młodymi ludźmi z Europy i całego świata podejmują ekumeniczne wysiłki prowadzące do budowania lepszego świata.

Wspólnota z Taizé jest ciągle przedmiotem zainteresowań wielu badaczy. Pośród nich można wymienić specjalistów z takich dziedzin jak socjologia, teologia duchowości, biblistyka, ekumenizm, muzykologia. Chcąc jednak zrozumieć lepiej fenomen Taizé, należy zagłębić się w historię początków powstania Wspólnoty. Podejmowane wysiłki badawcze bez odwołania się do historycznych fundamentów będą niepełne. Z pomocą niewątpliwie przychodzi prof. Silvia Scatena, wybitny historyk na Uniwersytecie w Modenie, która od 1995 roku współpracuje z Fundacją z Bolonii zajmującą się naukami o religiach. W swoim dorobku naukowym ma wiele publikacji z dziedziny historii religii, historii Kościoła. Wśród nich można znaleźć wiele tekstów poświęconych ekumenicznej Wspólnocie z Taizé, jak i jej założycielowi bratu Rogerowi. Najnowszym jej osiagnnięciem naukowym związanym z Taizé jest opublikowana w 2018 roku rozprawa naukowa 
wydana w ramach nowej serii Instytutu nauk religijnych w Bolonii oraz Fundacji Nauk Religijnych im. Jana XXIII. Tom 57 wspomnianej serii wydawniczej został zatytułowany: Taizé, una parabola di unità. Storia della comunità dalle origini al concilio dei giovani (Taizé, przypowieść o jedności. Historia Wspólnoty od jej założenia aż po sobór młodych).

Po lekturze obszernego dzieła liczącego dziewięć rozdziałów, należy stwierdzić, iż prof. Scatena bada bogatą, niepublikowaną dotąd dokumentację przechowywaną w Taizé oraz w wielu innych europejskich archiwach tak instytucjonalnych jak i prywatnych. Czyni to w sposób naukowy poddając krytycznemu opracowaniu zebrane źródła. Niewątpliwie jej praca jest odpowiedzią na istniejącą potrzebę pełnego spojrzenia, z punktu widzenia historii Kościoła, na powołanie i działalność Wspólnoty z Taizé. Prezentowana publikacja to owoc badań prof. Scateny nad pierwszymi dziesięcioleciami historii Wspólnoty założonej przez brata Rogera. Trzeba podkreślić, iż powstałe dzieło to efekt solidnej i skrupulatnej pracy autorki polegającej na przeprowadzeniu wywiadów, dotarciu do archiwów, zebraniu obszernej literatury związanej ze Wspólnotą oraz wielu archiwalnych źródeł historycznych. Autorka w swojej pracy wskazuje na wiele historycznych źródeł, które dotychczas nie były publikowane. Należy zauważyć, że prof. Scatena sięga często do francuskojęzycznych źródeł archiwalnych, które zawierają wiele ważnych kwestii, stąd też autorka często pozostawia je w języku oryginalnym. Dzieło jest obszerne. Na 876 stronach prof. Scatena analizując źródła koncentruje się na okolicznościach założenia Wspólnoty z Taizé oraz jej rozwoju. Ze względu na bogactwo źródeł jak i sam fenomen Taizé w Kościele, autorka w tytule swojej pracy postawiła granice czasowe. Analizuje w niej okres od założenia Wspólnoty, aż po sobór młodych zorganizowany w Taizé.

Profesor Scatena w swojej książce dokładnie śledzi początki gru-

Reports and reviews py współbraci, pastorów, profesorów i przyjaciół, od Lozanny po Strasburg. Autorka stara się odpowiedzieć na pytania: co motywowało brata Rogera do założenia Wspólnoty? Jakie były jej początki? Dlaczego wybrał Francję? Z jakimi trudnościami spotykali się bracia w pierwszych chwilach istnienia Wspólnoty? Skąd w monastycznym klasztorze pojawiło się tyle młodzieży z Francji, Europy i świata? Niewątpliwie te i inne pytania pojawiły się u autorki, a oddana do rąk czytelników monografia jest próbą odpowiedzenia sobie na powyższe pytania. Książka prof. Scateny jest przygotowana rzetelnie i profesjonalnie, co sprawia, że czytelnik może czuć się zwolniony 
z dodatkowego odwiedzania archiwów. Opublikowany tom powinien być zatem przedmiotem ogólnego zainteresowania tych, którzy chcą zagłębić się w historię początków Wspólnoty Taizé. 